This item was submitted to Loughborough's Research Repository by the author.

Items in Figshare are protected by copyright, with all rights reserved, unless otherwise indicated.

\title{
The importance of organisational issues in systems development
}

PLEASE CITE THE PUBLISHED VERSION

http://dx.doi.org/10.1108/09593849810218300

\section{PUBLISHER}

Emerald Group Publishing Limited (@ MCB University Press)

\section{VERSION}

AM (Accepted Manuscript)

\section{LICENCE}

CC BY-NC-ND 4.0

\section{REPOSITORY RECORD}

Doherty, Neil, and Malcolm King. 2019. "The Importance of Organisational Issues in Systems Development". figshare. https://hdl.handle.net/2134/13419. 
This item was submitted to Loughborough's Institutional Repository (https://dspace.lboro.ac.uk/) by the author and is made available under the following Creative Commons Licence conditions.

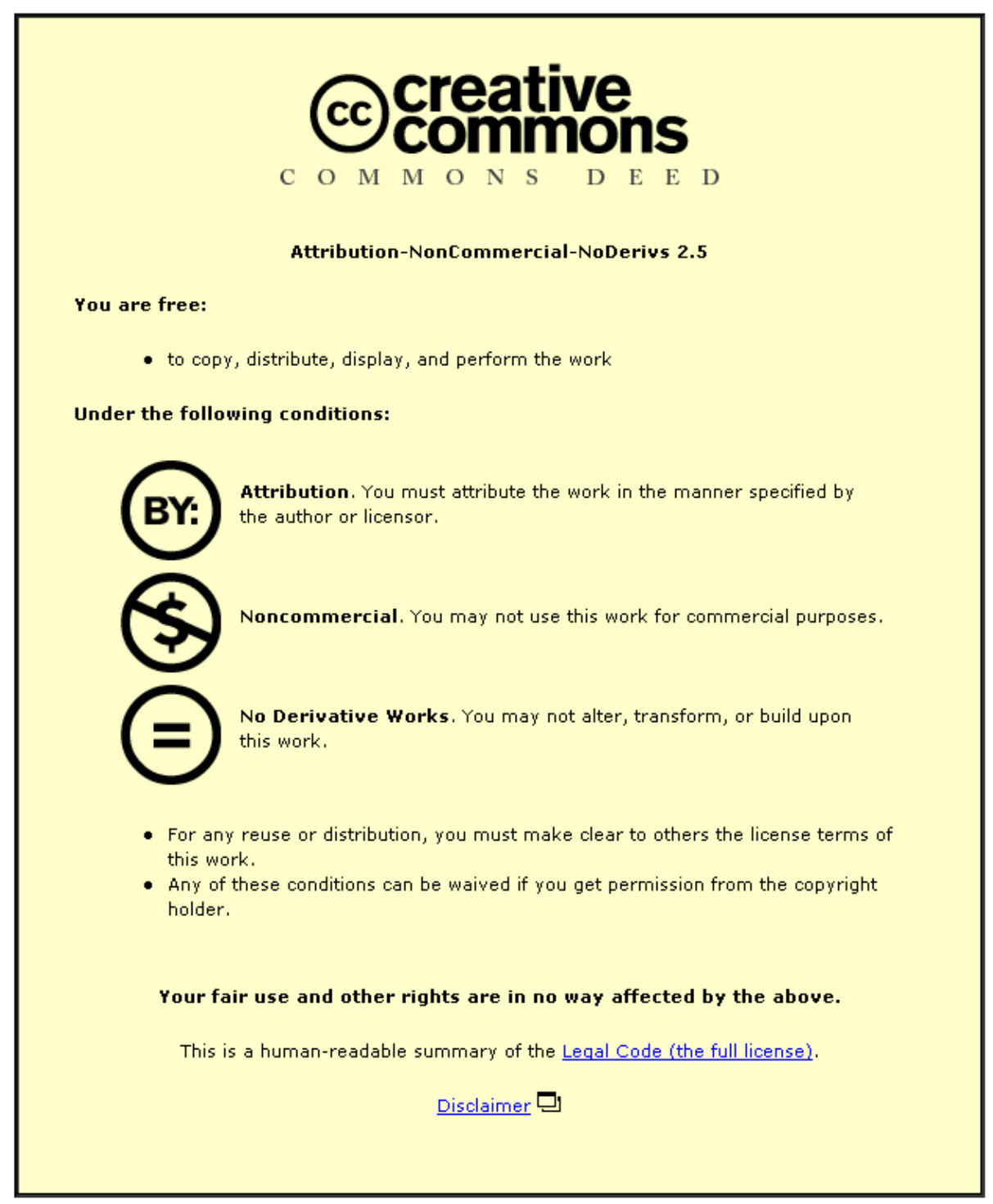

For the full text of this licence, please go to: http://creativecommons.org/licenses/by-nc-nd/2.5/ 


\title{
The Importance of Organisational Issues in Systems Development
}

\author{
N. F. DOHERTY, M. KING \\ (The Business School, Loughborough University, \\ Loughborough, LE11 3TU)
}

Mailing Address:

Professor Malcolm King,

Loughborough University Business School,

Loughborough University of Technology,

Loughborough, LE11 3TU,

United Kingdom.

Telephone: 01509223119

Fax:
Email: m.king@lboro.ac.uk

Email: n.f.doherty@lboro.ac.uk 


\title{
The Importance of Organisational Issues in Systems Development
}

Key Words: Systems development; Systems failure; Organisational issues; Organisational change; IT professionals; United Kingdom.

\begin{abstract}
A survey of senior and influential IT managers explored the related questions of why some senior IT professionals perceive organisational issues to be more important than technical issues, and whether this has a concomitant impact on the treatment of organisational issues. An overall response rate of $63 \%$ was achieved from a combined survey of two distinct groups. The results show that there are significant differences in managers' perceptions about the importance of organisational issues which can, to some extent, be explained in terms of organisational size, and to a lesser extent by the favoured development approach. However, these differences in perception appear to have no identifiable relation to the significant differences in the approaches adopted for treating organisational issues. It is suggested that this is due to the difficulties in treating such issues and further research to resolve these difficulties is proposed.
\end{abstract}




\section{INTRODUCTION}

Organisations of all shapes and sizes are having to embrace information technology enthusiastically if they wish to survive and hopefully thrive in an increasingly competitive environment. Consequently, the level of penetration and sophistication of information technology is growing rapidly, and with this goes a concomitant increase in the level of organisational impact. For example, the move from a number of standalone applications to the introduction of a fully integrated and distributed environmentwide information system is likely to have a significant impact on an organisation's culture, structure and working practices. Moreover, it is important to anticipate the nature of this organisational impact prior to systems implementation, as often a certain system cannot function within the organisational environment unless the system, the organisation or both are modified (Wijnhoven and Wassenaar, 1990).

Historically, information systems design has been preoccupied with technical issues at the expense of organisational issues. This is a dangerous strategy because there is a long stream of evidence to suggest that the treatment of organisational issues is perceived as more important than technical issues in determining the successful outcome of systems development projects (Lucas, 1975a; Long, 1987; Hornby et al, 1992, Ewusi-Mensah \& Przanyski, 1994). Unfortunately there is also much evidence to suggest that organisational issues are still not properly addressed during the systems development process (Eason, 1988; Hornby et al, 1992, Clegg et al, 1997). Despite the recognised importance of organisational issues, there has still been very little empirical research in this increasingly important area. To help fill this gap a research project was initiated to explore the relative importance of organisational issues and to investigate the approaches that are typically adopted for their treatment. The preliminary results of this project summarising the importance of, and treatment approaches for, organisational issues have already been published (Doherty and King, 1998). This paper presents a more sophisticated analysis of an extended data set exploring the factors affecting senior IT managers' perceptions of the importance of organisational issues.

The next section discusses the concept of organisational issues before the research method and objectives are discussed in section three. The research results are presented in a series of tables which are discussed in the fourth section and their importance is assessed in the final section. 


\title{
CONCEPTUAL BACKGROUND
}

This section seeks to establish a definition for the term 'organisational issue', then to review the perceived importance of such issues in the systems development process and finally to review the typical approaches applied to the treatment of organisational issues. In so doing the justification for this piece of research will be established.

\section{What are Organisational Issues: A Definition}

Concern with the topic of the treatment of organisational issues in the systems development process and consequently the origin of the term 'organisational issue' has come almost exclusively from the research conducted into the causes of information systems failure ((Ewusi-Mensah and Przasnyski, 1994), (Lederer and Nath, 1991), (Lyytinen and Hirschheim 1987)). Despite the growing body of research in this area and increasing recognition of the importance of this topic, there have been few attempts to explicitly define the term 'organisational issue'. Typically, organisational issues have been defined by providing examples of 'non-technical' aspects of systems development, which might have an impact on the ultimate success or failure of a project (Eason, 1988; Clegg et al, 1989).

The absence of an explicit definition for the term 'organisational issue', has proved to be something of a hindrance when developing research frameworks and instruments, and has motivated the authors to propose the following:

\begin{abstract}
'An organisational issue (in the context of information systems development) is any distinct area on the interface between a technical system and either the characteristics and requirements of the host organisation or its individual employees, which can lead to operational problems within the organisation.
\end{abstract}

The above definition is a generic definition and encompasses a wide variety of 'nontechnical' issues which need to be addressed during the systems development process, which other researchers have classified as organisational, behavioural, managerial, human or economic issues. Given the above definition it is immediately possible to classify issues such as: the impact of a system on an organisation's culture, working practices, or performance, and similarly, its impact on a user's motivation or performance, as organisational issues. However, other organisational oriented aspects of systems development such as the need for user participation, or the importance of 
senior management commitment would not be classified as organisational issues, as they are general approaches, rather than specific issues. Consequently, whilst active user participation, for example, may be of great importance to the treatment of a range of organisational issues, it cannot be classified as specific organisational issue in its own right.

Although the definition of organisational issues presented above helps in identifying specific issues that can be classified as organisational in orientation, it is important that the definition is tested in practice so that a definitive and widely accepted list of organisational issues can be established.

\section{The importance of organisational issues}

Concern with the relationship between information systems failure and organisational issues is not a new phenomenon. Henry Lucas (1975a) wrote a classic book over twenty years ago, in which he suggested that: 'the primary cause for systems' failure has been organisational behaviour problems'. There is much recent evidence to suggest that organisational issues are now becoming even more important and will become even more critical to the successful development and implementation of information systems than they were when Henry Lucas wrote his book. For example, Long (1987) has identified the fact that whilst only 10 per cent of failures in administrative applications are due to technical problems, 90 per cent can be accredited to organisational and managerial issues. Similarly Ewusi-Mensah \& Przanski (1991) conclude that when it comes to the factors that contribute to the abandonment of IS development projects it is 'organisational issues which are the most widespread and dominant of factors'. The contention that organisational issues are a major contributor to systems development failure or under performance is also supported by Kearney (1990); Buchannan (1991), Hornby et al (1992), Clegg et al (1997) and Ahn \& Skudlark (1997).

Whilst many researchers have highlighted the importance of organisational issues, there is still a requirement for more empirical research, especially with regard to the relative importance of specific issues. 


\section{The treatment of organisational issues}

Given the recognised importance of organisational issues, it is somewhat surprising that much recent research suggests that organisational issues are still not properly addressed during the systems development process (Eason, 1988; Hornby et al, 1992; Lim et al, 1992). This is probably because the systems development process is still primarily a technology driven process (Clegg et al 1997). Poulymenako and Holmes (1996) concur with this view, suggesting that the typical response to the problem of poorly performing systems has been to apply ever more rigorously the principles of engineering to the process of systems development. The technical orientation of systems development methodologies has typically resulted in the approach of implementing a system, and then trying to cope with its organisational implications.

Eason(1988) notes that the structured design methods, which are the most common means of developing complex and centralised systems, are typically devoted to the design of technical systems and give very little recognition or support to the range of organisational changes that also have to be designed. The work of Hornby et al (1992) supports this finding, in that common development methodologies, such as SSADM, Yourdon and SSAD, are still very technically oriented, with their treatment of organisational issues going very little beyond urging developers to involve the users. What is more, organisational issues are often completely ignored during systems development projects because there is a commonly held belief that organisational issues are not the concern of systems professionals (Newman, 1989; Hornby et al, 1992).

One obvious solution to the problem of technically oriented systems development methods is through the introduction of more participative, socio-technical methods. Enid Mumford has, for example, demonstrated impressive results with her ETHICS method (Mumford, 1986), whilst Bloomfield and Vurdubakis (1997) are strong advocates of the soft systems method as a way of 'incorporating the human, social and subjective elements of systems development'. Hirschheim et al ( 1997), Axtell et al (1997) and Avison and Taylor (1997) also suggest ways in which the organisational, human and social aspects of systems development can be addressed through the use of more participative methods. Unfortunately, the use of the more technically-oriented methods still predominate (Clegg et al, 1997), and as Mumford (1997) recently noted there are strong cultural barriers which still need to be broken down before participative methods become more widely adopted. 
Since it has been established that the treatment of organisational issues in commonly used systems development methodologies is at best patchy, there is need for empirical research to explore how, if at all, organisational issues are addressed.

\section{RESEARCH METHODOLOGY}

To investigate the views and perceptions of a wide range of senior IT professionals on the importance of organisational issues, and how they are addressed in practice, a survey-based approach was adopted. The survey was ultimately distributed to senior IT professionals in UK-based organisations in two phases. The choice of senior IT professionals as the 'key informants' (Venkatraman, 1988) was justified on the basis that they would be able to provide information on group or organisational attitudes and behaviour. Following the first phase a descriptive summary of IT manager's perceptions of the importance of organisational issues and the approaches adopted for their treatment was produced (Doherty and King, 1998). The aim of the second phase of the survey was to increase the number of responses so that it would be possible to conduct a more sophisticated analysis of the results. This section describes: how the questionnaire was designed and validated; the execution and summarised results of the first phase of the survey; and the rationale for, and the execution of, the second phase of the survey.

\section{The Design and Validation of the Questionnaire}

The research instrument was developed through an iterative process of review and refinement. The questionnaire was split into four major sections, the first of which sought to collect background information about the respondent's organisation, whilst the other three all focused on different aspects of the treatment of organisational issues. Table I summarises the important features of the questionnaire and indicates the primary sources from the literature that were used in its creation. These include both those which helped motivate the question, as well as those which aided in the operationalisation of variables.

\section{$\underline{\text { Take in Table I }}$}

The questionnaire was validated by a series of interviews and pre-tests with senior IT professionals which focused on issues of instrument clarity, question wording and validity. The pre-tests resulted in a number of important enhancements being made to the survey before it was distributed. In particular, it was possible to classify and extend 
the list of specific organisational issues. This classification with five categories is presented in table II.

\section{$\underline{\text { Take in Table II }}$}

The targeting, execution and summarised results of the first phase of the survey

The research instrument was distributed to a sample of 88 named individuals in a variety of UK-based organisations, all of whom had a high degree of managerial responsibility for systems development projects. Furthermore, all of the 88 targeted were individuals with whom the researchers had existing teaching, research or consultancy links, and therefore response rates could be expected to be high. A total of 64 valid responses were ultimately received, a highly encouraging response rate of $73 \%$. From these responses it was possible to produce some descriptive statistics with regard to IT managers' perceptions about the importance, and treatment of organisational issues, but there were insufficient responses to conduct any explanatory analysis. The results of this research can be summarised as follows:

- The Treatment of Organisational Issues: A surprisingly high proportion of the responding organisations, treat organisational issues explicitly (42\%), either during the feasibility study, requirements analysis or through an independent organisational impact analysis. Those organisations which only treat organisational issues implicitly is still, however, the largest single category with $49 \%$ of the responses, and a worrying $9 \%$ of the responding organisations rarely consider such issues.

- The Importance of Organisational Issues: The majority of the respondents (56\%) perceived that organisational issues were either 'the most important issue', or 'more important than technical issues', whilst a further 38\% felt that organisational issues were 'of equal importance to technical issues'. Therefore, only $6 \%$ of the respondents considered technical issues to be of more importance than organisational issues. Figure 1 provides a full break down of the responses to this question.

- The Treatment of Specific Organisational Issues: As might be expected, the frequency of systems development projects in which specific organisational issues are treated varies greatly. Some issues such as performing a cost-benefit analysis, or the need to consider systems interfaces are addressed in the vast majority of 
development projects, whilst others, in particular the distribution of power and the consideration of health \& safety issues, are rarely addressed.

- The Relative importance of Specific Organisational Issues: The relative importance of the 14 specific organisational issues is highly correlated to the frequency with which they are treated. More specifically, the issues which have been categorised as organisational contribution issues (see table II) are all highly ranked, whilst those categorised as organisational alignment are all lowly ranked.

A more detailed discussion of the development and validation of the questionnaire and a discussion of the full results of the descriptive analysis were reported in Doherty and King (1998). Whilst the results summarised above present some interesting insights into the treatment and importance of organisational issues, they don't look for relationships between different variables to answer why different managers perceive the importance of organisational issues and their treatment differently. To conduct a more sophisticated analysis a greater number of responses would be required, and consequently a second phase of questionnaire mailings was initiated. The aim, therefore, of this paper is to present the results of a more sophisticated analysis of the extended survey responses, by addressing the following three objectives:

- To use a second sample to verify the results of the initial survey, and in so doing ensure that there is no bias in the combined sample.

2 To investigate the factors which motivate some managers to perceive organisational issues to be of more importance, i.e. organisation size or type of project.

3 To investigate whether managers who perceive organisational issues to be of more importance treat such issues in a more focused and frequent manner.

\section{The Targeting and Execution of the Second Phase of the Survey}

To conduct a more detailed analysis of the data it was necessary to generate more responses. Unfortunately, identifying a source of named senior IT professionals from which a random sample could be derived proved to be impractical and, consequently, the following surrogate approach was adopted. The contents of computing trade and professional journals were carefully scrutinised over a period of three months in order to identify senior IT managers who were named in articles. Every senior manager who 
was named in an article was ultimately included in the sample, and therefore there was no bias introduced by selecting the type of article or the views expressed. It was felt that this was an appropriate way to collect a random sample of leading and influential IT managers. Ultimately, the second tranche of questionnaires was distributed to a total of 92 senior IT managers, none of whom were previously known to the researchers. This second survey resulted in a total of 43 usable questionnaires being returned, a highly encouraging response rate of $47 \%$. Table III provides an analysis of the level of response to the two mailings of the survey and provides a summary of the combined sample.

\section{Take in Table III}

The response rate for the second phase of the survey distribution is particularly good as the sample was completely random, and there was no prior relationship between the researchers and the respondents. It may very well be that this very high response rate is indicative of the interest in, and perceived importance of, this research.

\section{RESEARCH RESULTS}

The 107 usable questionnaire responses ultimately received were first entered into a spreadsheet, prior to transference to the statistics package SPSS, where a variety of analytical techniques were applied. This section presents a description of the application of the analytical tools, in addition to a detailed discussion of the results of the analysis. To make the discussion more meaningful the research findings are related to the three specific research objectives proposed earlier.

\section{Verification of the results of the initial survey}

The two samples were thoroughly evaluated to ensure that the assumption that they are both drawn from the same population could be tested. The following discussion of the comparison of the two samples concentrates on those variables which are utilised in the analysis of objectives 2 and 3.

Two primary tests were employed for this purpose: first, the chi-squared test was used to compare the distributions of 'categorical variables', whilst the t-test for independent variables was used for the 'numerical variables'. Table IV presents the results of all of the chi-squared tests that were conducted to test the similarity of the two samples. 


\section{$\underline{\text { Take in Table IV }}$}

It will be noted from the degrees of freedom that in some cases it was necessary to combine categories in an appropriate manner, in order to ensure that there were at least 5 observations in each cell. The results clearly demonstrate that the two samples can be considered together, since there is no evidence to suggest that the samples come from different populations, apart from in the case of the organisational sector variable. The reason that the distributions of the organisational sector variable differ is that the initial survey targeted a dis-proportionate number of manufacturing organisations and this imbalance was rectified in the second survey where a higher proportion of service organisations was targeted. Consequently, this result is of no great importance, as the combined sample is now more representative of the population at large.

When it came to comparing the distributions of the numeric variable 'the treatment of specific organisational issues' within the two samples, a t-test for independent samples was employed. The equalities of the means of all 14 specified variables were tested and the most significant t-statistic recorded was only 1.50 ( $d$ of $f=104$; significance $=$ 0.136 ), whilst all the rest were lower than 0.92 , which suggests that there is no evidence, at the usual level of confidence, to support the hypothesis that the two samples come from different populations.

In summary, none of the results of either the chi-squared tests, or the t-tests, provide any significant evidence that the two samples come from different populations. Consequently, for the remainder of the paper, the two separate samples will be treated as a single combined sample of 107 cases. Furthermore, it should be noted that the high response rates for both of the two independent samples and the differences in sampling methods provide added confidence that the combined sample is unbiased.

\section{Factors affecting perceptions about the importance of organisational issues:}

One of the most interesting results from this survey concerns the relative importance of organisational and technical issues when it comes to determining the ultimate success or failure of an information systems development project. Whilst much previous research has indicated that most systems development methodologies focus on technical issues at the expense of organisational issues, a significant majority of the respondents to this research felt that organisational issues are more important than 
technical issues. The majority of the respondents (56\%) perceived that organisational issues were either 'the most important issue', or 'more important than technical issues', whilst a further $38 \%$ felt that organisational issues were 'of equal importance to technical issues'. Therefore, only $6 \%$ of the respondents considered technical issues to be of more importance than organisational issues. Figure 1 provides a full break down of the responses to this question, and also graphically illustrates the similarity of the distribution of responses between the two phases of the survey.

\section{$\underline{\text { Take in Figure } 1}$}

The data presented in figure 1 indicates that there is variability in senior managers' perceptions of the importance of organisational issues. The aim of this section is to investigate whether there is an independent variable which is affecting, and may possibly explain, the differences in perception. More specifically, a chi-squared analysis was conducted to investigate whether there is a relationship between the size of an organisation, or the sector in which it operates, or its favoured development approach and the resultant perceived importance of organisational issues. In some cases of these analyses there were one or two missing values, leading to sample sizes of 105 or 106 instead of 107.

Organisational size: It might be hypothesised that senior IT managers coming from larger, and typically more sophisticated organisations might be more likely to perceive organisational issues to be of more importance. To investigate this supposition, a chisquared test was conducted and the results are presented in table $\mathrm{V}$ (the numbers in upright type in the table are actual values, and those shown in italics are the expected values for each cell).

\section{$\underline{\text { Take in Table } \mathrm{V}}$}

The results of this chi squared test are significant and the figures presented in table $\mathrm{V}$ clearly indicate that those IT managers coming from larger organisations are likely to perceive organisational issues to be of more importance, whilst those from smaller organisations are more likely to perceive them to be of equal or less importance than technical issues, which confirms the hypothesis.

Development Approach: It might be hypothesised that senior IT managers overseeing the implementation of packages might be more likely to perceive organisational issues to be of more importance than those who develop tailor-made 
solutions. The reasons for this hypothesis could be twofold. First, most technical issues have already been addressed by the original software designers so there are fewer technical issues to concern the user of the package and therefore organisational issues predominate. Conversely it could be that when using packaged software the scope for matching the software to the organisation is reduced and therefore it is necessary to match the organisation to the software, and therefore organisational issues predominate.

\section{$\underline{\text { Take in Table VI }}$}

The results of the chi-squared test, presented in Table VI, indicate that there is a very mild relationship between the systems development approach favoured and the perceived importance of organisational issues. More specifically, an inspection of the data suggests that organisations which favour packaged software are more likely to perceive organisational issues as being important, whilst those that favour tailor-made systems are less likely to perceive organisational issues as being more important than technical issues.

Organisational Sector: A chi-squared analysis to explore the relationship between an organisation's sector and the perceived importance of organisational issues was also conducted. As might be expected, there was no traceable relationship between the two.

Given that the differences in managers' perceptions about the importance of organisational issues can be explained in terms of organisational size and to a lesser extent the favoured development approach, one would expect this to be translated into differences in the treatment of issues. This assumption is tested in the following section.

\section{Factors affecting the treatment of Organisational Issues}

The approaches adopted for the treatment of organisational issues, as summarised earlier, suggest that there is high degree of variability. The aim, therefore, of this section is to investigate whether there is any relationship between the perceived importance of organisational issues and the treatment approach adopted.

The Overall Treatment Approach: All respondents to the survey were asked to identify which of a range of approaches to the treatment of organisational issues best 
matched the one that they typically utilised. The range of options offered included, 'rarely considered' and 'implicitly considered', as well as a selection of explicit approaches to their treatment. It was envisaged that those IT professionals who perceived that organisational issues are of greater importance than technical issues might be motivated to adopt more explicit approaches to their treatment. Consequently, a chi-square test was employed to test this hypothesis.

\section{$\underline{\text { Take in Table VII }}$}

Somewhat surprisingly, the results of the chi-squared analysis presented in table VII indicate that different perceptions of the importance of organisational issues are not translated into the adoption of different approaches to their treatment, and the splits between these differences are independent.

The Frequency of Treating Specific Organisational Issues: In addition to indicating the overall treatment approach that is typically adopted, respondents were also asked to comment on the proportion of systems development projects in which specific organisational issues are typically treated. More specifically, for each of the 14 specified issues (for example: 'the impact of the system on organisational culture', or 'the consideration of user motivation'), the respondent was asked to highlight on a five point scale, ranging ranging from $1=$ never to $5=$ always, the proportion of systems development projects in which the issue would be routinely addressed.

A summary of the results for each of the 14 specified issues is shown in table VIII. This table shows the overall average score (on the whole sample) for each specified issue in the second last column and the issues are arranged in descending order of these scores. Although not central to the purpose of this section, the table also shows the averages on each of the two samples from the first and second phase. In addition, in the final column, it shows the category that each issue belongs to as previously defined in table II. It is striking how well the categories and the overall order match up. This point and the comparison of the two sets of rankings will be considered in the discussion section.

\section{Take in Table VIII}

In trying to explain the variations noted earlier, it was envisaged that those IT professionals who perceived that organisational issues are of greater importance than technical issues might be motivated to treat organisational issues in a higher proportion 
of systems development projects. In this instance, the scores for each of the 14 specified organisational issues were averaged, and a comparison of means, using the independent samples t-test, was conducted to investigate this hypothesis.

\section{$\underline{\text { Take in Table IX }}$}

The results of the comparison of means test presented in table IX indicate that whilst the average score for the group of managers who believe organisational issues to be of more importance is higher, indicating that they treat them in a higher proportion of projects, the difference is not, however, statistically significant, and therefore it can not be concluded that the two sets of responses come from two different distributions. Consequently, it can be inferred that senior IT managers who perceive organisational issues to be of more importance than technical issues when it comes to determining the successful outcome of systems development projects, are no more likely to treat organisational issues in a higher proportion of systems development projects, than those who believe that organisational issues are only of equal or lesser importance to technical issues.

As the results of these tests of the relationship between the importance and treatment appeared counter intuitive, it was decided to initiate a final set of analyses to explore whether the differences in perceptions about the overall importance of organisational issues has any impact on their frequency of treatment when they are broken down. Rather than test each specified issue on its own, which could lead to a high chance of one of the 14 issues appearing significant purely randomly, it was thought better to split the 14 issues into the 5 discrete categories, as identified in table II. The average scores given in table VIII show a remarkable consistency within each category, with only two of the 14 out of place when they are put in descending order of the average score. This suggests that there is some validity to the categories and that it is appropriate to consider them together. This is further demonstrated in table $X$ which shows the issues grouped by category and displays the overall category average. Apart from the two issues already alluded to, the variation between the issues within each category is less striking than that between the categories.

\section{$\underline{\text { Take in Table } X}$}

To pursue the assumption that differences in perceptions about the overall importance of organisational issues might have an impact on their frequency of treatment, it was decided to test whether there might be significant differences for one or more of the 5 
categories, even if the overall means were not significantly different. Consequently, a comparison of means, using the independent samples t-test once more, was conducted to investigate this hypothesis.

\section{$\underline{\text { Take in Table XI }}$}

The results presented in table $\mathrm{XI}$ indicate that in four categories out of five the mean for the group of managers who perceive organisational issues to be of more importance are higher. When the test statistics are investigated, however, the difference in means is clearly not significant in all but one instance. In the case of the organisational contribution category, the higher mean for the group who perceive organisational issues to be of more importance, is mildly significant.

Hence, even when the frequency of utilisation is broken down into its constituent categories there are still no major differences between the actions of senior IT managers who perceive organisational issues to be of more importance than technical issues when it comes to determining the successful outcome of systems development projects, and those who believe that organisational issues are only of equal or lesser importance to technical issues. Thus there appears to be no significant relationship between the perceived importance of organisational issues and the way in which these issues are treated. This surprising finding is considered further in the following discussion.

\section{DISCUSSION}

Although not one of the three major objectives of this paper, the results presented in table VIII are important. The table shows the average scores reported for the frequency of treatment of the 14 specified organisational issues, both overall and for the two samples generated in the two phases. The issues are arranged in descending order of the averages (based on the combined sample) and alongside the averages for each of the two constituent samples the ranking of the scores in descending order is given. This shows that both the scores and even the rankings are very consistent between the two samples. The first seven issues and the last one are in the same order in both samples. Those numbered between 8 and 12 are still consistent since in sample 2 there are three simple reversals by one position compared to sample 1 . Not only does this lend weight to the argument that the samples are consistent and can be combined, but it also shows that this set of issues leads to stable scorings, with quite noticeable variations between the issues. 
It is also encouraging to see that these frequency scorings tie in with the categorisation suggested earlier for the 14 specified organisational issues. These categories were derived from consideration of their content and so it is encouraging that respondents unaware of this categorisation nevertheless scored them in a way very consistent with the categories. Apart from the Training and Education requirements issue and the organisational structure issue, the issues all group together by their category when ranked in order of frequency. This strengthens the validity of these categories and suggests they could be used in further research. It is important to note that the overall scores confirm the sample 1 results which showed the differences in the frequency scores. In particular, the four issues in the Organisational Contribution category have high scores indicating they are nearly always considered whereas the issues in the Organisational Alignment category, which many authors argue are also critical for success, receive scores which indicate they are rarely considered.

The finding that there is no relationship between the perceived importance of organisational issues, and their treatment is obviously worrying as it suggests that many managers who perceive organisational issues to be of more importance than technical issues, in determining the successful outcome of systems development projects, are only treating those issues implicitly, or in many cases not at all. This result can probably best be explained in terms of previous research which suggests that IT professionals haven't the time, the tools nor the expertise to effectively address organisational issues (Hornby et al, 1992; Clegg et al, 1997), no matter how important they think they are, and consequently their treatment is often woefully inadequate. Consequently, in too many cases, their treatment is left to chance.

This view is supported by many of the respondents who accepted the opportunity to provide supplementary comments, which helped to throw more light on their survey answers. From these comments it was possible to establish that many senior IT professionals accepted that organisational issues are often given a low priority and only 'lip service' is paid to their treatment, because they are generally difficult to address. The reasons respondents gave for this included their intangible, ambiguous and politically sensitive nature. As a result, no one is keen to take the responsibility for their treatment and inevitably it often 'falls down the gap' between the IT professionals and the user managers. Furthermore, because of the tight time and cost constraints within which systems are developed, it is likely that organisational issues will be ignored in the interests of developing a technically sound system on time and within budget. It also was interesting to note, from respondents comments, that in a number 
of cases even where they treated organisational issues explicitly, this had later been qualified by the observation that they do not find it possible to treat all of the issues explicitly.

Despite the concerns about the treatment of organisational issues, a number of constructive suggestions were volunteered. These included: the need for integrated IT and user development teams; organisational ownership of systems from an early stage in the development process; and the importance of formal change management programmes, whose focus should spread well beyond the boundaries of the technical system. The most significant point, perhaps, was the recognition that both the user and IT communities must grow closer together and become far more aware of each others' requirements and motivations. This last point highlights the need to initiate far broader programmes of awareness, education and training for all participants in the systems development process.

\section{CONCLUSIONS}

The research presented in this paper addresses an increasingly important subject, namely the importance and treatment of organisational issues during the systems development process. The primary conclusions are that there continue to be significant variations in the perceptions of senior IT managers about the importance of organisational issues in the successful development of information systems, and also significant variations in the way in which these issues are treated. Whilst the differences in managers' perceptions about the importance of organisational issues can, to some extent, be explained in terms of organisational size and, to a lesser extent, by the favoured development approach, this has no significant impact on the approach they adopt for their treatment. This last point is perhaps the most important finding from this piece of research, and the implications discussed earlier need to be carefully considered by senior IT professionals.

The results from the research show the benefit of defining a range of specific organisational issues. The 14 specific issues used in this paper have been shown to achieve stable scores for frequency of use over different samples of IT specialists. Further, this work indicates the usefulness of categorising organisational issues and proposes 5 robust categories which link those with similar concerns and which achieve similar scores over a wide ranging sample. It is suggested that this categorisation may be a useful tool for future research. 
This research confirms the continuing importance and increasing awareness of organisational issues and highlights the need to address them explicitly during the systems development process. There is, however, much further detailed research that needs to be undertaken to explore how organisational issues are treated, both in terms of methods and timing, who is responsible for conducting their treatment, the resultant success of such treatments and the factors which are inhibiting the effective treatment of organisational issues. More importantly, however, it is essential that any research is translated into the development of a range of practical tools, methods and strategies which will support the systematic and integrated consideration of organisational issues during the systems development process.

\section{$\underline{\text { Acknowledgements }}$}

The authors would like to take the opportunity to thank all those IT professionals who took the time and trouble to respond to the questionnaire, especially those who were involved in the piloting exercise. 


\section{$\underline{\text { References }}$}

Ahn, J. \& Skudlark, A (1997) "Resolving conflict of interests in the process of an information system implementation for advanced telecommunication services", Journal of Information Technology, Vol. 12, pp. 3-13.

Axtell, C., Waterson, P. \& Clegg, C. (1997) "Problems integrating user participation into software developments, Int. J. Human-Computer Studies, Vol. 47, pp.323-345.

Avison, D. \& Taylor, V. (1997) Information systems development methodologies: a classification according to problem situation", Journal of Information Technology, Vol. 12, pp. 73-81.

Bloomfield, B. P. \& Vurdubakis, T. (1997) "Visions of the organisation and organisations of vision: the representational practices of systems development", Accounting, Organisations and Society, Vol. 22, No. 9, pp. 639-668.

Buchannan, D. (1991), "Figure-ground reversal in Systems Development \& Implementation: From $\mathrm{HCl}$ to OSI. in Nurminen, M. \& Weir, G. (eds), Human Jobs and Computer Interfaces", North Holland, Amsterdam, pp. 213-226.

Clegg, C., Warr, P., Green, T., Monk, A., Allison, G. \& Landsdale, M. (1989), People and Computers: How to evaluate your company's new technology, Ellis Horwood, Chichester.

Clegg, C., Axtell, C., Damadoran, L., Farbey, B., Hull, R., Lloyd-Jones, R., Nicholls, J. Sell,R. \& Tomlinson, C. (1997) "Information Technology: a study of performance and the role of human and organisational factors", Ergonomics, Vol. 40 No. 9, pp. 851-871.

Doherty, N.F. and King, M. (1998) "The Importance of Organisational Issues in Systems Development" , Information Technology \& People , 11(2), pp 104-123

Eason, K., (1988), Information Technology and Organisational Change, Taylor \& Francis, London.

Ewusi-Mensah, K. \& Przasnyski, Z. (1991) "On Information Systems Project Abandonment: An Exploratory Study of Organizational Practices", MIS Quarterly, March, pp. 67-85.

Ewusi-Mensah, K. \& Przasnyski, Z. (1994) "Factors Contributing to the Abandonment of Information Systems Development Projects", Journal of Information Technology, Vol. 9, pp. 185-201.

Hirschheim, R., Klein, H. \& Newman, M. (1997) "Information Systems Development as Social Action: Theoretical Perspective and Practice, OMEGA, Vol. 19, No. 6, pp. 587-608.

Hornby, C., Clegg, C., Robson, J., McClaren, C., Richardson, S. \& O'Brien, P. (1992) "Human \& Organisational Issues in Information Systems Development", Behaviour \& Information Technology, Vol. 11 No. 3, pp. 160-174.

Kearney, A. T. (1990), Barriers to the successful application of Information Technology, DTI \& CIMA, London.

Lederer, A. L. \& Nath R. (1991) "Managing Organisational Issues in Systems Development", Journal of Systems Management, Vol 24 No 11, pp. 23-27.

Lim, K., Long, J. \& Silcock, N. (1992) "Integrating Human Factors with the Jackson System Development Method: An Illustrated Overview", Ergonomics, Vol 35 No 10, pp. 11351161.

Long, R. J. (1987), New Office Information Technology: Human and Managerial Implications, Croom Helm, London.

Lucas, H. C. (1975), Why information systems fail, Columbia University Press, New York.

Lyytinen K. and Hirschheim R. (1987) "Information Systems Failures: A Survey and Classification of the Empirical Literature", Oxford Surveys in Information Technology. Vol 4, pp. 257-309. 
Mumford, E. (1986), Using computers for business success: The ETHICS method, Manchester Business School, Manchester.

Mumford, E. (1997), "The reality of participative systems design; contributing to stability in a rocking boat", Information Systems Journal, Vol. 7, No. 4, pp. 309-321.

Newman, M. (1989) "Some fallicies in information systems development", International Journal of Information Management, Vol. 9, pp 127-143.

Sauer, C. (1993), Why Information Systems Fail: A Case Study Approach, Alfred Waller, Henley.

Poulymenako, A.\& Holmes, A. (1996) "A Contingency framework for the investigation of information systems failure", EJIS, Vol 5, pp. 34-46.

Venkatraman, N. (1989) "The Strategic Orientation Of Business Enterprises - The Construct, Dimensionality, and Measurement", Management Science, Vol 35 No 8, pp. 942-962.

Wijnhoven and Wassenaar (1990) "The Impact of IT on Organisations: The State of the Art", International Journal of Information Management, Vol 10, pp. 35-53. 
Table I: Variable Operationalisation

\begin{tabular}{|c|c|c|}
\hline Variable & Measure & Primary Sources \\
\hline Organisational size & $\begin{array}{l}\text { A four point scale, measuring organisational size } \\
\text { by the number of employees. }\end{array}$ & \\
\hline Organisational sector & $\begin{array}{l}\text { A three point scale to identify the primary sector } \\
\text { that the organisation operates in }\end{array}$ & \\
\hline $\begin{array}{l}\text { Favoured development } \\
\text { approach }\end{array}$ & $\begin{array}{l}\text { A six point scale to measure the percentage of IS } \\
\text { projects which deliver 'tailor-made', as opposed } \\
\text { to packaged software. }\end{array}$ & \\
\hline $\begin{array}{l}\text { Overall treatment } \\
\text { approach }\end{array}$ & $\begin{array}{l}\text { A six point scale to identify the primary approach } \\
\text { to the treatment of organisational issues. } \\
\text { Options included 'rarely considered', 'implicitly } \\
\text { considered' in addition to a selection of explicit } \\
\text { approaches. }\end{array}$ & $\begin{array}{l}\text { Eason (1988); Sauer } \\
\text { (1993) }\end{array}$ \\
\hline $\begin{array}{l}\text { Relative importance of } \\
\text { organisational issues }\end{array}$ & $\begin{array}{l}\text { A five point scale to measure the relative } \\
\text { importance of organisational issues, as opposed } \\
\text { to technical issues, in determining the ultimate } \\
\text { success of systems development projects. }\end{array}$ & $\begin{array}{l}\text { Ewusi-Mensah \& } \\
\text { Pryzanski (1991); } \\
\text { Buchannan (1991) }\end{array}$ \\
\hline $\begin{array}{l}\text { The treatment of specific } \\
\text { organisational issues }\end{array}$ & $\begin{array}{l}\text { A five point scale, ranging from always to never, } \\
\text { to measure the proportion of projects in which } \\
14 \text { specified organisational issues are treated. } \\
\text { The } 14 \text { specified objectives were sub-divided into } \\
\text { five categories, as highlighted in Table II. }\end{array}$ & $\begin{array}{l}\text { Eason (1988); Clegg et } \\
\text { al (1989); Hornby et al } \\
(1992)\end{array}$ \\
\hline $\begin{array}{l}\text { The relative importance } \\
\text { of specific organisational } \\
\text { issues }\end{array}$ & $\begin{array}{l}\text { A ranking scale to explore the relative } \\
\text { importance of the same } 14 \text { specified } \\
\text { organisational issues. }\end{array}$ & $\begin{array}{l}\text { Eason (1988); Clegg et } \\
\text { al (1989); Hornby et al } \\
\text { (1992) }\end{array}$ \\
\hline
\end{tabular}


Table II: The categorisation of organisational issues

\begin{tabular}{|c|c|c|}
\hline Category & Title \& Definition & Organisational issues \\
\hline \multirow[t]{5}{*}{1.} & Organisational contribution: & \\
\hline & \multirow{4}{*}{$\begin{array}{l}\text { Those issues which focus on ensuring that a proposed } \\
\text { system will make a positive contribution to some part of } \\
\text { the organisation. }\end{array}$} & Cost-benefit analysis \\
\hline & & IS strategy alignment \\
\hline & & Prioritisation of deliverables \\
\hline & & Future needs of the organisation \\
\hline \multirow[t]{4}{*}{2.} & \multicolumn{2}{|l|}{ Organisational Alignment: } \\
\hline & The group of organisational issues which need to be & Impact on organisational culture \\
\hline & considered in order to ensure that the proposed system & Impact on organisational structure \\
\hline & and its host organisation are well matched. & Impact on distribution of power \\
\hline \multirow[t]{5}{*}{3.} & \multicolumn{2}{|l|}{ Human Issues: } \\
\hline & These are issues which have a discernible impact upon & Identify training needs \\
\hline & the working practices and conditions of individual & Health and safety / ergonomic impact \\
\hline & \multirow[t]{2}{*}{ employees who interact directly with the system } & Level of user motivation \\
\hline & & Redesign of jobs \\
\hline \multirow[t]{3}{*}{4.} & \multicolumn{2}{|l|}{ Transitional issues: } \\
\hline & This category includes issues which relate to practical & Level of organisational disruption \\
\hline & $\begin{array}{l}\text { organisational issues which need to addressed to ensure } \\
\text { that the transition from old to new system is problem } \\
\text { free. }\end{array}$ & Timing of implementation \\
\hline \multirow[t]{2}{*}{5.} & \multicolumn{2}{|l|}{ Systems integration issues: } \\
\hline & $\begin{array}{l}\text { These are issues which have a direct impact on the } \\
\text { dissemination and use of information. }\end{array}$ & Interfaces to existing systems \\
\hline
\end{tabular}

Table III: Summary of Survey Responses

\begin{tabular}{lccc}
\hline Phase & Surveys Posted & Responses & Response Rate \\
\hline Phase 1 & 79 & 64 & $73 \%$ \\
Phase 2 & 92 & 43 & $47 \%$ \\
Total & 171 & 107 & $63 \%$ \\
\hline
\end{tabular}


Table IV: Results of chi-squared tests comparing the two samples

\begin{tabular}{lccc}
\hline & \multicolumn{3}{c}{ Chi-square test statistics } \\
Variable & Value & D. of F. & Significance \\
\hline Organisation Size & 0.27 & 1 & 0.60 \\
Organisation Sector & 9.51 & 2 & 0.01 \\
Favoured Development Approach & 0.11 & 1 & 0.74 \\
Overall treatment approach & 2.27 & 2 & 0.32 \\
Importance of organisational issues & 1.15 & 1 & 0.28 \\
\hline
\end{tabular}

Table V: The relationship between the size of an organisation, and the perceived importance of organisational issues

\begin{tabular}{l|c|c|c}
\hline Organisation size & $\begin{array}{c}\text { Org. issues of equal, or } \\
\text { less, importance than } \\
\text { technical issues }\end{array}$ & $\begin{array}{c}\text { Org. issues more } \\
\text { important than } \\
\text { technical issues }\end{array}$ & Totals \\
\hline Organisation $<1000$ & $\mathbf{1 6}$ & $\mathbf{1 1}$ & 27 \\
Employees & 11.1 & 15.9 & 80 \\
\hline Organisation $>=1000$ & $\mathbf{2 8}$ & $\mathbf{5 2}$ & 107 \\
Employees & 32.9 & 67.1 & \\
\hline Totals & 44 & 63 &
\end{tabular}

Result significant at the $5 \%$ level; $c^{2}=4.91>3.841=c^{2}(0.05), 1 d f$.

Table VI: The relationship between the development approach favoured, and the perceived importance of organisational issues

\begin{tabular}{l|c|c|c}
\hline & $\begin{array}{c}\text { Org. issues of equal, or } \\
\text { less, importance than } \\
\text { technical issues }\end{array}$ & $\begin{array}{c}\text { Org. issues more } \\
\text { important than } \\
\text { technical issues }\end{array}$ & Totals \\
\hline$<50 \%$ of IT systems & $\mathbf{2 0}$ & $\mathbf{3 8}$ & 58 \\
tailor-made & 23.8 & 34.2 & 47 \\
\hline$>50 \%$ of IT systems & $\mathbf{2 3}$ & $\mathbf{2 4}$ & 105 \\
tailor-made & 19.2 & 27.8 & 62 \\
\hline Totals & 43 &
\end{tabular}

Significant at the $15 \%$ level; $c^{2}=2.24>2.072=c^{2}(0.15), 1 d f$.

Table VII: The relationship between the perceived importance of OI, and their treatment in the systems development process

\begin{tabular}{l|c|c|c}
\hline & $\begin{array}{c}\text { Org. issues of equal, or } \\
\text { less, importance than } \\
\text { technical issues }\end{array}$ & $\begin{array}{c}\text { Org. issues more } \\
\text { important than } \\
\text { technical issues }\end{array}$ & Totals \\
\hline $\begin{array}{l}\text { Org issues treated } \\
\text { rarely or implicitly }\end{array}$ & $\mathbf{2 4}$ & $\mathbf{3 1}$ & 55 \\
\hline Org issues treated & 22.83 & 32.17 & 51 \\
explicitly & $\mathbf{2 0}$ & $\mathbf{3 1}$ & 106 \\
\hline Totals & 21.17 & 62 & 14 \\
\hline
\end{tabular}

Not significant at the $50 \%$ level; $c^{2}=0.213<0.455=c^{2}(0.50), 1 d f$. 
Table VIII: The frequency with which individual organizational issues are addressed

\begin{tabular}{l|cc|cc|c|c}
\hline \multirow{2}{*}{ Organizational Issue } & \multicolumn{2}{|c|}{$\begin{array}{c}\text { Sample 1 } \\
\text { (64) }\end{array}$} & \multicolumn{2}{c|}{$\begin{array}{c}\text { Sample 2 } \\
\text { (43) }\end{array}$} & $\begin{array}{c}\text { Combined } \\
\text { (107) }\end{array}$ & Category \\
\cline { 2 - 6 } & Ave. & Rank & Ave. & Rank & Ave. & \\
\hline Consider System's Interfaces & 4.4 & 1 & 4.4 & 1 & 4.38 & 5 \\
Undertake Cost-benefit Analysis & 4.1 & 2 & 4.2 & 2 & 4.16 & 1 \\
Align with Information systems strategy & 4.1 & 3 & 4.1 & 3 & 4.11 & 1 \\
Assess Training and education requirements & 4.0 & 4 & 3.9 & 4 & 3.99 & 3 \\
Prioritize work to focus on critical areas & 3.8 & 5 & 3.8 & 5 & 3.80 & 1 \\
Consider future needs of the organization & 3.6 & 6 & 3.8 & 6 & 3.67 & 1 \\
Review timing of implementation & 3.6 & 7 & 3.8 & 7 & 3.67 & 4 \\
Consider level of organizational disruption & 3.4 & 8 & 3.2 & 9 & 3.31 & 4 \\
Re-design jobs to suit system & 3.2 & 9 & 3.3 & 8 & 3.24 & 3 \\
Assess impact on organizational structure & 3.0 & 10 & 3.1 & 11 & 3.00 & 2 \\
Assess the system's impact on user & 2.9 & 11 & 3.2 & 10 & 3.00 & 3 \\
motivation & & & & & & 3 \\
Consider health and safety / ergonomic & 2.7 & 12 & 2.6 & 13 & 2.65 & 3 \\
issues & & & & & & 2 \\
Assess impact on organizational culture & 2.6 & 13 & 2.7 & 12 & 2.65 & 2 \\
Evaluate the impact on the distribution of & 2.0 & 14 & 2.0 & 14 & 2.00 & 2 \\
power & & & & & & 3 \\
\hline
\end{tabular}

Table IX: The relationship between the perceived importance of OI, and the frequency of their treatment in the systems development process

\begin{tabular}{lcccc}
\hline $\begin{array}{l}\text { Frequency of } \\
\text { Utilisation }\end{array}$ & $\begin{array}{c}\text { Org. issues of equal, } \\
\text { or less, importance } \\
\text { than technical issues }\end{array}$ & $\begin{array}{c}\text { Org. issues more } \\
\text { important than } \\
\text { technical issues }\end{array}$ & $\begin{array}{c}\text { T-test } \\
\text { statistic } \\
\text { (d of f) }\end{array}$ & $\begin{array}{c}\text { Signif- } \\
\text { icance }\end{array}$ \\
\hline Overall Means & 3.33 & 3.46 & -1.17 & 0.244 \\
& & & $(101)$ & \\
\hline
\end{tabular}


Table X: The frequency with which organizational issues are addressed by category

\begin{tabular}{|c|c|c|c|}
\hline Organizational Issue & Category & $\begin{array}{l}\text { Individual } \\
\text { Average }\end{array}$ & $\begin{array}{l}\text { Category } \\
\text { Average }\end{array}$ \\
\hline Undertake Cost-benefit Analysis & 1 & 4.16 & \\
\hline Align with Information systems strategy & 1 & 4.11 & \\
\hline Prioritize work to focus on critical areas & 1 & 3.80 & 3.94 \\
\hline Consider future needs of the organization & 1 & 3.67 & \\
\hline Assess impact on organizational structure & 2 & 3.00 & \\
\hline Assess impact on organizational culture & 2 & 2.65 & 2.55 \\
\hline $\begin{array}{l}\text { Evaluate the impact on the distribution of } \\
\text { power }\end{array}$ & 2 & 2.00 & \\
\hline Assess Training and education requirements & 3 & 3.99 & \\
\hline Re-design jobs to suit system & 3 & 3.24 & \\
\hline Assess the system's impact on user motivation & 3 & 3.00 & 3.22 \\
\hline Consider health and safety / ergonomic issues & 3 & 2.65 & \\
\hline Review timing of implementation & 4 & 3.67 & \\
\hline Consider level of organizational disruption & 4 & 3.31 & 3.49 \\
\hline Consider System's Interfaces & 5 & 4.38 & 4.38 \\
\hline
\end{tabular}

Table XI: The relationship between the importance of organisational issues and the treatment of different categories of organisational issue.

\begin{tabular}{lcccc}
\hline $\begin{array}{l}\text { Frequency of } \\
\text { Utilisation }\end{array}$ & $\begin{array}{c}\text { Org. issues of equal, } \\
\text { or less, importance } \\
\text { than technical issues }\end{array}$ & $\begin{array}{c}\text { Org. issues more } \\
\text { important than } \\
\text { technical issues }\end{array}$ & $\begin{array}{c}\text { T-test } \\
\text { statistic } \\
(d \text { of } f)\end{array}$ & $\begin{array}{c}\text { Signif- } \\
\text { icance }\end{array}$ \\
\hline $\begin{array}{l}\text { Organisational } \\
\text { Alignment }\end{array}$ & 2.47 & 2.61 & $\begin{array}{c}-0.77 \\
(97)\end{array}$ & 0.445 \\
Human Issues & 3.14 & 3.27 & $\begin{array}{c}-0.91 \\
(97)\end{array}$ & 0.367 \\
& & & 0.12 & 0.901 \\
$\begin{array}{l}\text { Transitional } \\
\text { Issues }\end{array}$ & 3.48 & 3.50 & $(94)$ & \\
$\begin{array}{l}\text { Systems } \\
\text { Interfaces }\end{array}$ & 4.32 & 4.42 & -0.62 & 0.540 \\
$\begin{array}{l}\text { Organisational } \\
\text { Contribution }\end{array}$ & 3.83 & 4.01 & $\begin{array}{c}(78) \\
-1.57\end{array}$ & 0.120 \\
\hline
\end{tabular}




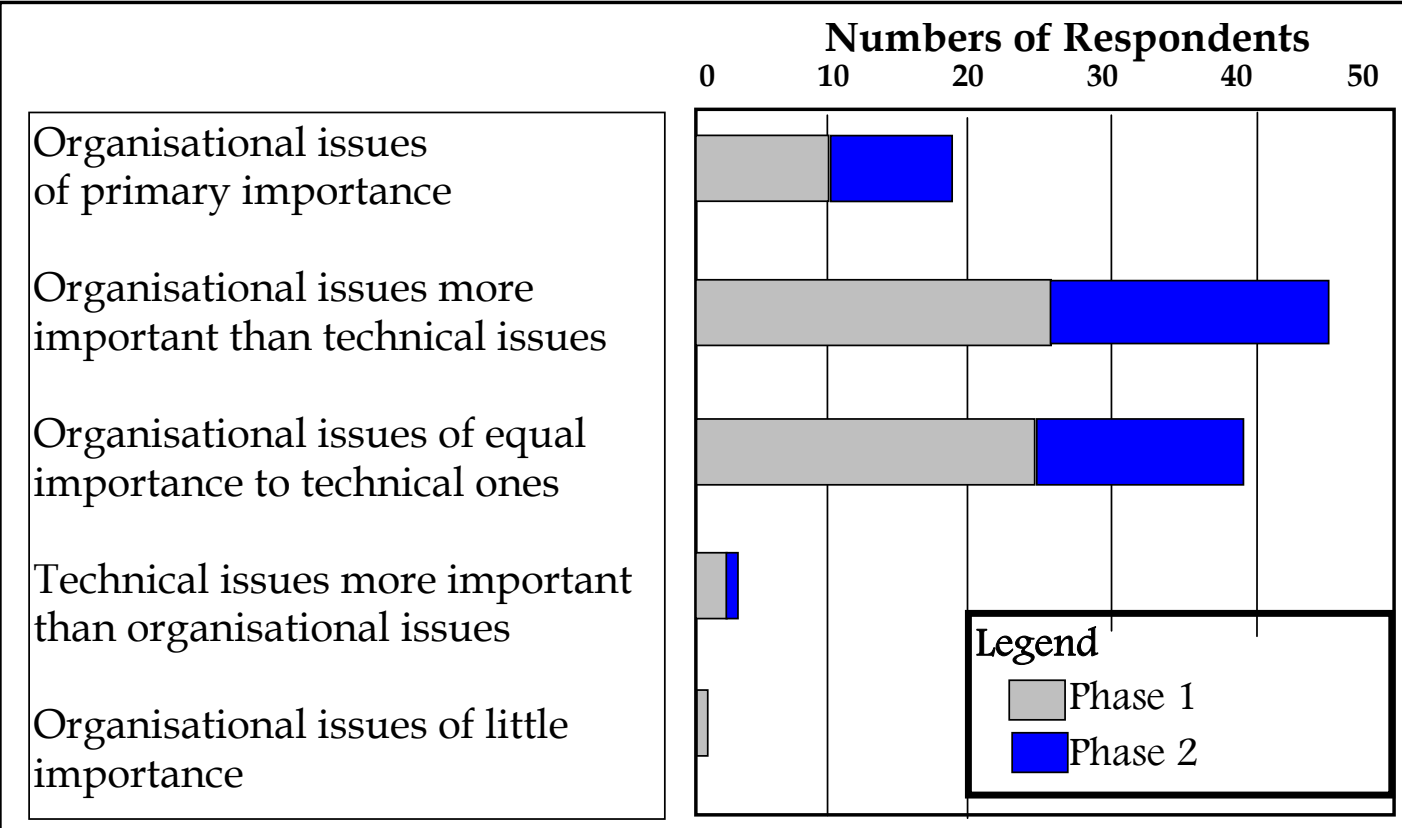

Figure 1: The Relative Importance of Organisational Issues 